\title{
Environmental risks insurance in Slovakian market
}

\author{
Adriana Csikósová1,", Mária Janošková2 ${ }^{2}$ and Katarina Čulková ${ }^{1}$ \\ ${ }^{1}$ Technical university of Košice, Park Komenského 19, 04201 Košice, Slovakia \\ ${ }^{2}$ Catholic university in Ružomberok, Námestie Jána Pavla II. 15, 05801 Poprad, Slovakia
}

\begin{abstract}
.
Research background: Environmental policy becomes actual worldwide problem and globalization process is closely related with rising of environmental risks. To manage such process needs to accept preventive measurements, but also to apply financial mechanisms for remediation of possible environmental damages.

Purpose of the article: Presented contribution is orientated to the evaluation of possible insurance of environmental risks.

Methods: The main approach to research is analysis of environmental taxes in tax system of Slovakia, when data had been obtained from tax system SR.

Findings \& Value added: Analysis showed there are the so called normative means (orders, bans, directives, norms, regulations etc.), financial-economic means (environmental taxes and fees) and voluntary means (EMS, EMAS, and Environmental Labeling etc.). One of useable financial means is to prevent the appearance of environmental risks. Countries have different forms of environmental insurance. The developed economies have a wide spectrum of insurance products and different approaches of insurance of environmental risks contributing to the minimization of the consequences of environmental damages. Information from the contribution can be used as financial guarantee for potential polluters and in the field of environmental risks management, as well as providing of financial securities of the companies. The limitation of the research is difficulty to obtain data, especially in area of environmental risks insurance there is only small amount of historical data to evaluate the situation.
\end{abstract}

Keywords: insurance; living environment protection; company; environmental risks; Slovak republic

JEL Classification: $L 10 ; Q 52$

\footnotetext{
* Corresponding author: adriana.csikosova@tuke.sk
} 


\section{Introduction}

Environmental policy and protection of living environment, orientated to the environmental burden decreasing becomes actual worldwide problem and part of national and multinational economic policies. Global environmental challenges create risks and opportunities for companies in different sectors, which are driven by such challenges to actions. Concerning proactive environmental actions, the focus is typically on large companies [1,2]. Empirical evidence suggests that large companies are more likely to address environmental risks strategically than smaller companies [3, 4]. The need for studying driving forces behind proactive environmental actions of insurers is based on the ever growing pressure on insurers to deal with environmental issues, damages and related risks [5, 6, 7]. The study of Johannsdottir (2015) emphasizes the type of stakeholder's insurance companies are in a position of influence, including customers, suppliers and authorities [8]. The results have a theoretical implication, as the literature has not covered this subject in the context of insurance of environmental risks behind proactive environmental actions and the role of insurers as a driving force of proactive environmental actions of the companies, causing possible environmental damages. A practical implication for the insurance sector includes increased awareness about proactive environmental behavior, knowledge about lack of drivers in the companies, knowledge about what stakeholder's insurers are providing insurance of environmental risks. The study suggests that the environmental behavior behind actions of financial companies do not necessarily follow the pattern of other sectors covered in the literature: it may therefore be sectorspecific and they may differ within a single industry setting. The institutional environment plays an important role, even in countries with similar characteristics and a similar national institutional context. The paper as investment tool that responds to mine management issues, including also technical causes, policy examples, technical remedies, and principles for successful long-term management, studies insurance [9].

Management of environmental risk process is connected with accepting of normative tools, respectively with legislation, orientated to the area of prevention before rising of industrial emergencies, to the area of applying of polluter's responsibilities for environmental damages, but also remediation of old burdens. At the same time together with acceptance of normative environmental tools importance is given also to financial and economical tools, among which important position belongs to environmental taxes and fees [10].

In last time there is still greater importance given to so-called "soft legislation" that includes voluntary tools. It means reflective regulation, connected with using of "selfreflective" accesses of the companies, polluters of living environment. Such companies are not object of regulation from the side of institutions, responsible for quality of living environment, but also according their own decision they became part of regulation process. Voluntary tool can be considered also systems of environmental management (EMS and EMAS), but also marking of environmentally proper products, etc.

Presented contribution is orientated to possible limitation of negative externalities of environmental risks, with acceptance of principles of revenue neutrality, relating to the economic subjects, sectors of national economy in area of impact to the cost decreasing, technological changes, competitiveness, payment ability, etc. Except of fiscal and stimulation, effect environmental risks have important impact to the establishment of ecoinnovation activities and processes of business environment subjects. 


\section{Present state of problem solving - literature review}

Making environmental damage caused by industrial accidents and restoring impaired ecosystems may be associated with high costs, therefore European Environmental Liability Directive requires that environmental damage is prevented or remediated by environmental risks insurance [11, 12]. Baumol and Oates (1972) pointed to negatives of environmental risks, developing and modifying concept of management of living environment quality [13]. From the view of international space and from the view of influence to the living environment, Miranda and Hale (2002) are also leaning to the idea as „environmental risks“ [14]. In the case of incomplete environmental liabilities insurance, company is threaten by bankruptcy and rational enterprises generally do not want to insure the environmental loss liability in case of bankruptcy even if they are compensated by insurance companies [15].

Boonen (2019) studied market with insurances from the view of optimal insurance, when insurer is protected by limited liability, and the multivariate insured risk is exchangeable, showing existence of an equilibrium in the market [16]. Moreover, current pollution insurance products have limited risk coverage, high premium rates, and low loss ratios, which make them unattractive to polluters. Meanwhile, low awareness of environmental and social liabilities leads to limited demand for pollution insurance products by industrial companies. Hence, the pollution insurance market is not yet flourishing [17]. In this connection, Yang et al. (2017) proposed new insurance product safety and environmental pollution liability insurance as an important supplement to the current safety and environmental risk prevention and control system [18]. In addition, Noda (2019) pointed to the disability insurance from an environmental policy perspective, showing that the emissions tax rate is always lower in the presence of disability insurance than it is in the absence of disability insurance [19].

Insurance of environmental risks have effects of bankruptcy protection, when through insurance company can improve environmental outcomes and risk reduction [20]. Borisova et al. (2019) proved that the application of proper methodology of environmental risk assessment and analysis enables to determine the goals of the regional development strategy and to justify a risk level acceptable for the regions by the insurance reserve fund for the conservation in order to improve the environmental safety [21]. Still pollution insurance faces a number of challenges.

\section{Methodology}

The goal of the contribution is to analyze position and importance of environmental taxes establishment in V4 region. To achieve determined goal, there was made analysis of environmental taxes in tax system of Slovakia, development of tax rates and collection of environmental taxes.

During realization of the research secondary data and database of tax subjects of environmental tax of electricity, coal and earth gas had been applied. The data had been obtained from tax system of Slovak Republic, obtained through portal of Financial Administration of Slovakia and portal of financial statements FinStat.sk, as well as information of taxation in Czech Republic, Poland and Hungary according Eurostat database. We resulted from the decree of European Commission that defines environmental tax according Methodology of Eurostat ESA 95 and Decree No 691/2011 about European environmental economic accounts as tax ,when tax base is physical unit that has negative impact to the living environment". According European Commission (2016) ecologic taxes includes for the Eurostat energetic taxes, taxes from transport, taxes from pollution and taxes of sources. As illustrated in classification, among ecological taxes belong also fees that are defined as obligatory, not refundable payment to public budgets and extra 
budgetary funds that could be seen as payment for certain ecologic services. Value added tax, given to the goods that have negative influence to the living environment, is excluded according to this methodology from the group of environmental taxes. For processing of obtained results, methods of description statistics, contingent tables and tools of graphical illustration had been used.

With respect to requirements for harmonizing in area of living environment authorities of the European Union adopted Directive 2004/35/EC on environmental liability with regard to the prevention and remedying of environmental damage that had been implemented by the Member States to their law (OECD, 2015) [22]. The Directive is based on the prevention principle and polluter pays principle. Slovak Republic has transposed a European directive in the form of a separate law No 359/2007 Coll. "On the prevention and remedying of environmental damage".

Financial providing of polluter responsibility for covering of environmental damages is framed by the availability of financial resources of polluter that at some stage of his activities may or may not have the necessary extent available. Probability of such situation creates the conditions for the transfer of environmental risk to the insurance company.

In developed economies, a wide range of insurance products has developed, covering various damages and some of them cover subjective and objective responsibility, which may include:

- Environmental Impairment Liability - offering cover of damages, caused by third party. It means health and life emergencies, property damage, cost for removing or decreasing of pollution, as well as covering of costs for damages removing. Damages on biodiversity and covering of costs for removing of pollution from area of single operation are excluded from the insurance.

- Coverage for On-site Cleanup Liability - it means damages covering, rising for insured, while there are covered costs for pollution removing in area of operation. Such insurance is supplement of Environmental Impairment Liability.

- Remediation Stop Loss - covering costs for renovation of living environment pollution in case invested costs have overreached planned level. It is used mainly for covering of risks and uncertainties, connected with works on remediation of damages on living environment. Only damages, rising for insured, are covered from this insurance.

- Contractors Pollution Legal Liability - this insurance had been used formerly by companies, providing services in area of removing of living environment pollution, for example removing of contaminated materials from the soil. Insurance is source for covering of demands on responsibilities of living environment damages that would rise due to the performed activity.

- Transportation Coverage - covering risks, connected with accidents that can rise during transport of dangerous substances.

- Environmental Coverage for Landfills - product orientated to the damages, caused by operators of underground storage of waste that is regularly modified in connection to the clients' needs. Due to the modification, there is high difficulty for covering of environmental risk not only during stock service, but also after its termination [23].

\section{Result of environmental risks insurance in Slovakian market}

Law No 359/2007 Coll., provides for subjects' necessity to be financially secure against possible implementation of the environmental damage to 2012. The first insurance company in Slovakia, which provided insurance product for responsibility for environmental damage since 2008, was the Allianz Slovak insurance company. Based on the report of the Slovak Insurance Association it was at the beginning of 2012 the only 
insurance company providing insurance fully complying with the requirements of the Act on prevention and remedying of environmental damage. Currently, several insurers offer the insurance in Slovakia as a separate insurance product. An overview is in Table 1.

Table 1. Insurers offering insurance of environmental damage responsibility in Slovakia

\begin{tabular}{|l|l|}
\hline \multicolumn{1}{|c|}{ Insurer } & \multicolumn{1}{c|}{ Insurance product } \\
\hline AIG Europe limited & Enviro Pro \\
\hline Alianz Slovenská poist'ovňa & Insurance of environmental damage responsibility \\
\hline Generali Poist'ovňa & Insurance of environmental damage responsibility \\
\hline Kooperativa & Enviro MAX \\
\hline UNIQA & Insurance of environmental damage responsibility \\
\hline Komunálna poist'ovňa & Enviro Plus \\
\hline HDI & Insurance of general responsibility \\
\hline Groupama Garancia poist'ovňa & Insurance of general responsibility \\
\hline
\end{tabular}

Table 2 gives review of insurance covering of environmental damage responsibility in mentioned insurance companies.

Table 2. Insurance of environmental damage responsibility in Slovakia

\begin{tabular}{|c|c|c|c|c|c|c|c|c|}
\hline \multirow[t]{2}{*}{ Insurance coverage } & \multicolumn{8}{|c|}{ Insurance Company } \\
\hline & $\underset{⿱ ㇒}{\longleftarrow}$ & 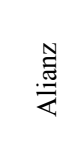 & $\begin{array}{l}\bar{\pi} \\
\overline{0} \\
\overline{0} \\
0\end{array}$ & 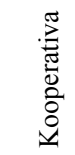 & 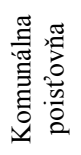 & $\frac{\nwarrow}{\precsim}$ & 在 & 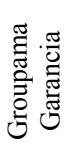 \\
\hline Cost of preventive measurements & Yes & Yes & Yes & Yes & Yes & No & Yes & Yes \\
\hline $\begin{array}{l}\text { Cost of primary, supplement, } \\
\text { compensation remedy }\end{array}$ & Yes & Yes & Yes & Yes & Yes & Yes & Yes & Yes \\
\hline Sudden and random pollution & Yes & Yes & Yes & Yes & Yes & Yes & Yes & Yes \\
\hline Gradual pollution & Yes & No & No & Yes & No & No & No & No \\
\hline $\begin{array}{l}\text { Technical costs (legal services, } \\
\text { monitoring, expert review) }\end{array}$ & Yes & Yes & & Yes & Yes & No & No & No \\
\hline $\begin{array}{l}\text { Reimbursement of costs of civil } \\
\text { proceedings }\end{array}$ & Yes & Yes & Yes & Yes & No & No & No & No \\
\hline $\begin{array}{l}\text { Own costs for cleaning and } \\
\text { decontamination }\end{array}$ & Yes & No & No & Yes & No & No & No & No \\
\hline $\begin{array}{l}\text { Cleaning of living environment } \\
\text { in state ownership }\end{array}$ & Yes & Yes & Yes & Yes & Yes & Yes & Yes & Yes \\
\hline $\begin{array}{l}\text { General responsibility (property } \\
\text { damages, health damages) }\end{array}$ & Yes & Yes & No & Yes & Yes & No & Yes & No \\
\hline Own break of operation & No & No & No & Yes & No & No & No & No \\
\hline Product & No & No & & No & No & No & Yes & No \\
\hline Transport & No & No & No & Yes & No & No & No & No \\
\hline Retroactivity & Yes & No & No & Yes & No & No & No & No \\
\hline
\end{tabular}

Insurer AIG offer to various subjects' insurance product EnviroPro that provides insurance coverage in the frame of European Direction 2004/35/EC and legislation No $359 / 2007$. But insurer does not offer only basic covering, but also product, including number of various coverages, among which there is for example covering of monitoring and determination of damage volume, covering of property and health damage, technical costs and defense costs, etc.

Allianz Slovakian Insurance Company acts officially in Slovak insurance market since 2003, but its reformation from Slovak Insurance Company to Allianz Slovakian Insurance Company begin yet in 2001. Presently it is biggest insurance company in 
Slovakia, offering insurance product for covering of environmental damage responsibility that provides insurance protection against costs, invested to avoiding of immediate threatening of environmental damage, but also to already realized damages on living environment. Insurance is related also to the technical costs, including finances, invested for legislative services, emergency commissioners, expert reviews, etc. Insurer is obligated to pay also covering of reimbursement of the costs of civil proceedings. Further product is covering also damage on health and property for third subject.

Generali Poist'ovňa is part insurance group Generali PPF Holding that is one of biggest in Middle and Eastern Europe. In present time, it belongs among three strongest insurers in Slovakian market. It provides insurance in the frame of its portfolio since April 2012 following the effectiveness of $\S 14$ of the Act No 359/2007 Coll., which provides financial security obligation. Insurance is defined for production companies, but also for companies providing services. It provides insurance coverage according available legislation, which means covering of costs of primary, compensation and supplement remedy in case of environmental damage realization and costs of preventive measurements in case of immediate threat of environmental damage. It includes also possibility for insurance of environmental damage, caused by product.

Kooperativa Poist'ovňa rose in $30^{\text {th }}$ October 1990 as first private universal insurance company in Slovakia. It is member of strong European concern Vienna Insurance Group. During last years, it obtained Communal Insurance Company and Slovak Savings Bank, and by this way it increased its market rate to level $34,5 \%$. It is regularly at rank of five strongest insurers in Slovakia. In the frame of responsibility insurance, it offers product Insurance of responsibility for environmental damage "Enviro MAX".

Komunálna poist'ovňa started to act in Slovakian insurance market in 1994. It is orientated to the area of life and non-life insurance (insurance of industrial risks, property, vehicles, responsibilities). In 2001, insurance company became member of strong international concern Vienne Insurance Group. Insurer is working in area of big risks with strong reinsurances, such as MUNICH Re, Hannover Re, SCOR Paris, and Swiss Re. For potential polluters it provides products Enviro Plus that bring the client insurance covering in full extend given by legislation. Insurance means, „claims made“, during environmental damage insurer covers preventive measurements for avoiding of living environment damage.

UNIQA Poist'ovňa presents universal insurance company offering its clients broad spectrum of insurance protection in area of non-life and live insurance. It acts in Slovakia since 1990, when it raised as insurance company OTČINA, a.s. IN 1999 company merged with Bundesländer Versicherung, Reiffeisen Versicherung and Austria Collegialität Austrian concern UNIQA Group Austria. Product for insurance of environmental damage responsibility provides also full insurance protection in the frame of available legislation.

HDI Versicherung AG acts in Slovakian insurance market since 2009 when it takes the strain of former insurer HDI Gerling Slovakia, a.s. Its target segment are industrial companies, mainly energetics, electro technics, construction industry, engineering and general production. Insurance is provided also for companies, acting in area of business and services. Its portfolio of products includes also basic insurance of responsibilities, technical risks, transport and property insurance. It is orientated to the individual insurance needs of clients, offering customized products. Product „Insurance of environmental damage responsibility“ is offering since July 2010 as a possibility for reinsurance to general responsibility.

Groupama Garancia poist'ovňa raised in France as cooperative insurance company, raised by farmers that wanted to be protected against fires and natural disasters. Lately it was developed and it started to insure also insuring dangers of various characters. In Slovakia it acts since 2009 when it raised by acquisition OTP Garancia poist'ovňa, a. s. and 
OTP Garancia životná poist'ovňa, a. s. It provides life insurance, as well as non-life insurance and its products are available in clients' centers of OTP Bank. Insurance of environmental damage responsibility is offering as reinsurance to general responsibility. It covers costs of preventive measurements and costs of primary, supplement and compensation remedy in case of realization of living environment damage that occurred randomly and unexpectedly. Product provides only basic protection, since it means reinsurance and it is proper mainly for clients in Groupama Insurance Company.

\section{Discussion}

Based on analysis of insurance products at Slovak insurance market we can state that it provides a sufficient amount of insurance products. The range of coverage between them is a wide variety of products and company can choose from basic coverage to insurance coverage of transportation, product and service interruption.

Kooperativa insurance company with its products "Enviro MAX" provides its clients widest coverage in the Slovak insurance market. It covers all of the attributes that can be related to the occurrence of environmental damage, e.g. necessity to interrupt current operations, own cost of the land decontamination, and expert reviews. On the other hand, insurance coverage at a large number of insurance dangers and needs of those who take up insurance is questionable. Another product is EnviroPro from AIG. Those two insurances should provide for potential polluters coverage for almost all insurance dangers, related to environmental damage.

Although insurance is not the only possible way of financial guarantee for potential polluters as defined in Slovak legislation, it is still the most used method in the field of environmental risks. According to the report of the Slovak Insurance Association, in 2012 there is no information about the involvement of other subjects in this area, although ways how to insure are also, for example, a bank guarantee or a guarantee fund. In Slovakia, all the major insurance companies already offer environmental insurance and environmental damages require large and financially strong partner. Therefore, it is probable that insurance companies with lower insurance portfolio and capital do not plan in the future to provide such insurance. It is in case of insurance UNION, Inc., ČSOB Insurance Company, Inc., Astra Insurance Agency, Inc. etc. Another reason is the fact that the greatest interest in the insurance of environmental risks in Slovakia was to the date of rising of efficiency about obligation of financial security. It was in situation, when the companies, which has to have obligation of financial providing for possible environmental damages within the meaning of the Act and companies have to demonstrate financial security for such damages.

Another problem in insuring environmental risks presents their nature and complexity. The probability of realizing such damage is small, but in case of its rising it reaches large financial dimensions. The insurers have over other insurance risks a more difficult task with regard to the underlying data. In case of responsibility of environmental risks insurance there is only small amount of historical data, from which insurers might expect the frequency and extent of damages on the living environment and, consequently, to create a quality insurance product, to determine adequate insurance and to ensure sufficient financial capacity. Moreover, there is a problem of risk anti selection when the insurer receives to insurance narrow range of major players who are aware of the high probability of causing environmental damage, but it means for the insurance company small portfolio with high risk, which cannot be differentiated by entry of smaller operators with lower risk of the insured event. 


\section{Conclusion}

The contribution emphasized shortages and limitations in area of insurance problems in connection with generally binding environmental legislative decrees from the view of EU and Slovakia. Further orientation of the contribution problems is connected with application of insurance in mining sector. The importance of this connection is confirmed by results of risk research in mining organizations, in connection with influence of mining activity to the living environment, to the property, to the inhabitants and employees of the organization. Mentioned is caused due to the risky activity of mining organization with direct influence to the living environment and people.

Results of the contribution research would be typing of environmental risks during mining and processing of limestone and typing of environmental risks during mining and processing of gravel. The aim is to emphasize that in case of environmental damage rising, such damage would not mean only damaging of living environment, but it can also cause significant negative impact to the mining organization activity, to its goodwill and to the public relations.

Contribution is partial result of project financed by Slovak Agency VEGA No. 1/0651/18 "Research of institutional environment influence to the corporate social responsibility, consumers' satisfaction and performance of the company".

\section{References}

1. Chih, H. L., Chih, H. H., Chen, T. Y. (2010). On the determinants of corporate social responsibility: International evidence on the financial Industry. Journal of Business Ethics, 93(1), 115-135.

2. Klettner, A., Clarke, T., Boersma, M. (2014). The governance of Corporate Sustainability: Empirical Insights into the Development, Leadership and Implementation of Responsible Business Strategy. Journal of Business Ethics, 122(1), $145-165$.

3. Chen, Y.S. (2008). The driver of green innovation and green image - green core competence. Journal of Business Ethics, 81(3), 531-543.

4. Singh, N., Jain, S., Sharma, P. (2014). Determinants of proactive environmental management practices in Indian firms: an empirical study. Journal of Cleaner Production, 66, 469-478.

5. Field, C.B., Barros, V., Stocker, T.F., Qin, D., Dokken, D.J., Ebi, K.L., Mastrandrea, M.D., Mach, K.J., Plattner, G.K., Allen, S.K., Tignor, M., Midgley, P.M. (2012). Managing the Risks of Extreme Events and Disasters to Advance Climate change Adaptation. Special Report of the Intergovernmental Panel on Climate Change. IPPC, Cambridge \& New York: Cambridge University Press. Retrieved from: www.ipcc.ch/ report/managing-the-risks-of-extreme-events-and-disasters-to-advance-climate-changeadaptation/

6. IPCC. (2013). Agreed Reference Material for the IPCC Fifth Assessment Report. Retrieved from: http://www.ipcc.ch/pdf/ar5/ar5-outline-compilation.pdf.

7. UNFCCC. (2008). Report of the Conference of the Parties on its Thirteenth Session, Held in Bali from 3 to 15 December 2007. Decisions adopted by the Conference of the Parties. Retrieved from: http://unfccc.int/resource/docs/2007/cop13/eng/06a01. pdf\#page $=3$ 
8. Johannsdottir, L. (2015). Drives of proactive environmental actions of small, medium and large Nordic non-life insurance companies - and insurers as a driving force of actions. Journal of Cleaner Production, 108, 685-698.

9. Kempton, H., Bloomfield, T.A., Hanson, J.L., Limerick, P. (2010). Policy guidance for identifying and effectively managing perpetual environmental impacts from new hardrock mines. Environmental Science \& Policy, 13(6), 558-566.

10. Romančíková, E. (2004). Finančno-ekonomické aspekty ochrany životného prostredia. Bratislava: ECO INSTRUMENT.

11. Staccione, A., Mysiak, J., Ostoich, M., Marcomini, A. (2019). Financial liability for environmental damage: insurance market in Italy, focus on Veneto region experience. Environmental Science and Pollution Research, 26(25), 25749-25761.

12. Faure, M.G., Partain, R.A. (2019). Insurance for Environmental Damage. Environmental law and economics: Theory and Practice, 233-252.

13. Baumol, W.J., Oates, W.E. (1971). The use of Standards and Prices for the Protection of the Environment. Swedish Journal of Economics, 73, 53-65.

14. Miranda, M.L., Hale, B.W. (2002). A taxing environment: Evaluating the multiple objectives of environmental taxes. Environmental Science and Technology, 36(24), 5289-5295.

15. Ma, B.J., Ye, J.Y., Liu, G., Huang, Y.J. (2020). Adverse selection, limited compensation, and the design of environmental liability insurance contract in the case of enterprise bankruptcy. Managerial and Decision Economic, 41(7), 1327-1337.

16. Boonen, T.J. (2019). Equilibrium recoveries in insurance markets with limited liability. Journal of mathematical economics, 85, 38-45.

17. Feng, Y., Mol, A.P.J., Lu, Y.L., He, G.Z., van Koppen, C.S.A. (2014). Environmental Pollution Liability Insurance in China: In Need of Strong Government Backing. AMBIO, 43(5), 687-702.

18. Yang, Y., Lan, Q.Z., Liu, P.J., Ma, L. (2017). Insurance as a market mechanism in managing regional environmental and safety risks. Resources Conservation and Recycling, 124, 62-66.

19. Noda, H. (2019). Disability insurance and environmental tax policy in a zero net emissions society. Applied Economics Letters, 26(18), 1485-1493.

20. Boomhower, J. (2019). Drilling Like There's No Tomorrow: Bankruptcy, Insurance, and Environmental Risk. American Economic Review, 109(2), 391-426.

21. Borisova, V., Samohkina, I., Rybina, L., Kobzhev, O. (2019). Formation of the Environmental Insurance System to Improve the Environmental Safety of the State: The Case of Ukraine. International Journal of Ecology and Development, 34(1), 127 140.

22. OECD / EEA. (2015). Database on Instruments used for environmental policy and natural resources management. Retrieved from: www2oec.org/ecoinst/querie

23. Korauš, A. (2007). Environmental insurance. Proceedings of the International Conference "Management of Environment 2007", Jaslovské Bohunice (pp. 1-8). Retrieved from: www.sszp.eu/wp-content/uploads/b_16-Koraus-1.pdf 